\title{
The wage gap in accounting positions
}

\author{
MARA VOGT ${ }^{1}$ \\ EDMERY TAVARES BARBOSA ${ }^{2}$ \\ MARCIA ZANIEVICZ DA SILVA ${ }^{1}$ \\ ARNo PAULO SCHMITZ ${ }^{3}$ \\ ${ }^{1}$ Universidade Regional de Blumenau (FURB) / DePARTMENT OF ACCOUNTING, BLUMENAU - SC, BRAZIL \\ 2 Universidade federal da Paraíba (UfPB) / Department of Finance and Accounting, JoÃo Pessoa - PB, BraziL \\ ${ }^{3}$ Universidade Federal do Paraná (UfPR) / Department of TeChNological Education, Curitiba - PR, Brazil
}

\begin{abstract}
This research aimed to describe the wage differences among accounting occupations in Brazil. A descriptive, documental, and quantitative research was carried out with auditors, accountants, and accounting assistants (occupations defined by the Código Brasileiro de Ocupações CBO). The study used regressions with binary variables analyzing data from 2009 to 2015. The results showed that low wages are significant among female black or mulatto workers; workers who completed high school and do not have a degree; with a disability; and in their first job or hired under a fixed-term contract. Also, the study observed that individuals who receive a higher wage are accountants, caucasian male, between 30 and 39 years old, holding a degree, and not disabled. The individuals with higher wages have work experience (they are at least in their second work contract), are employed in a company with up to four employees, and are residents of the Southeast region of Brazil.
\end{abstract}

Keywords: Wage gap. Determinant factors. Accounting occupations. The human capital theory. The segmentation theory.

\section{Fatores determinantes das diferenças salariais entre as ocupações da contabilidade}

\section{Resumo}

Com o objetivo de descrever os fatores determinantes das diferenças salariais entre os profissionais da contabilidade no Brasil, foi realizada uma pesquisa descritiva, documental e quantitativa dos profissionais com os cargos de Auditor, Contador e Auxiliar Contábil (segundo o Código Brasileiro de Ocupações - $\mathrm{CBO}$ ). Os resultados a partir do uso de regressões com variáveis binárias e, no contexto das variáveis analisadas (para os anos entre 2009/2015) são: a) os baixos salários são significativos entre as profissionais do gênero feminino que se declararam negras ou mulatas, com ensino médio, alguma deficiência e que estão no primeiro emprego ou contratadas por tempo pré-estabelecido; b) o indivíduo que tende a receber um salário mais elevado é o ocupante do cargo de Contador, homem, branco, entre 30 e 39 anos de idade, com ensino superior completo e não é deficiente. Adicionalmente, este indivíduo atua, pelo menos, em um segundo emprego, trabalha em uma empresa com até quatro funcionários e é residente da região Sudeste do Brasil.

Palavras-chave: Diferença salarial. Fatores determinantes. Ocupações contábeis. Teoria do capital humano. Teoria da segmentação.

\section{Determinantes de las diferencias salariales entre los puestos contables}

\section{Resumen}

Para describir los determinantes de las diferencias salariales entre los profesionales de contabilidad en Brasil, se realizó una encuesta descriptiva, documental y cuantitativa de profesionales con los cargos de auditor, contador y asistente de contabilidad (de acuerdo con el Código Brasileiro de Ocupações - CBO). Los resultados del uso de regresiones con variables binarias y, en el contexto de las variables analizadas (para los años de 2009 a 2015) son: a) los bajos salarios son significativos entre las profesionales que se declararon negras o mulatas, con educación secundaria, alguna discapacidad y que están en su primer trabajo o contratadas por un tiempo preestablecido; b) la persona que tiende a recibir un salario más alto es quien tiene el cargo de contador, hombre, blanco, entre 30 y 39 años de edad, con educación superior completa y sin discapacidad. Además, esta persona trabaja, al menos, en un segundo empleo, trabaja en una empresa con hasta cuatro empleados y es residente de la región Sudeste de Brasil.

Palabras clave: Diferencia salarial. Factores determinantes. Puestos contables. Teoría del capital humano. Teoría de la segmentación. 


\section{INTRODUCTION}

In the contemporary world, wage variation is a feature of the labor market. The determinants of this variation are explicit factors such as skills, knowledge, schooling, and implicit/discriminatory characteristics, for example, due to gender, ethnicity and religion. The modern society, even in developed countries, has not suppressed the differentiated remuneration (wage, bonus, and others) that usually privileges some individuals. Especially those linked to issues extrinsic to the needs for an occupation.

To eradicate wage discrimination practices, many people should be aware of it (all parts of the governments, the community leaders, the educators, and the researchers, etc.). Furthermore, it should be understood as such practices empirically occur at the different levels of the development and in certain spheres analysis. Examples of these spheres are economic, social and cultural (these should be assessed by the country and the geographical areas), business feature (size and sector of economic activity) and peculiarities of certain occupations.

There is a wage inequality in several areas, and this has attracted the attention of several researchers from different theoretical approaches. Among the contributions to understanding this theme are the Human Capital Theory and the Segmentation Theory. The Human Capital Theory, whose precursor is Mincer (1958), that reveals the existence of a relation between investments in education and training of the population and the income distribution.

Some years later, Becker (1964) verified empirically that training and production improvement are the consequences from the investments in education. In other words, education makes people more productive, increasing their wages, which directly affects the economic growth. Therefore, the income of the workers tends to grow according to accumulated human capital.

On the other hand, the Segmentation Theory postulates that workers may have different wages even if they are equally productive. Therefore, the segmentation occurs when workers have similar productive characteristics, but their wages differ. Thus, the wage inequality can be derived from the difference between geographical regions, prejudices as to ethnicity, gender, job experience, among others (SOUZA, 1978).

Each theory presents factors related to the employability and remuneration (sum of the wage, bonus, etc.) of the workers, according to the behavior of the labor market. Both theories seek to explain wage differentiation in the labor market. However, the Human Capital Theory is related on knowledge and training, while the Segmentation Theory is inspired by other issues or factors linked to location or rigid intrinsic characteristics (ethnicity, religion, gender, etc.).

Related to this problem, several researches in the accounting area have focused attention to wage inequality and long-term career development and barriers to occupation of certain prestigious positions in accounting (SILVA, DAL MAGRO and SILVA, 2016; HAYNES, 2017).

In Brazil, where cultural diversity coexists with the 'myth of racial democracy', income misdistribution having a significant impact on socioeconomic and regional development. In addition, the different levels of appropriation of education, health and other public services imply on the access to employment opportunities. The regional context is also identified as one of the factors that can determine the wage differential (FIELDS and YOO, 2000; SILVA, DAL MAGRO and SILVA, 2016). However, few researches relate to the thematic of relationship between the profile of accounting positions and their wages, a limitation to which this research proposes to unveil.

In this regards, according with studies focused on the analysis of discriminatory characteristics in specific scenarios, the following research question presents itself: What factors explain the wage gap (consider sum of the wage, bonus, etc. like remuneration) between accounting positions? Consequently, the aim is to describe the personal and contextual factors that explain the occurrence of wage differences between the positions and people who work in the Brazilian accounting area. The personal factors to be investigated are gender, ethnicity, age, schooling, kinds of disability and working time (experience); and contextual factors that are: size of the company and geographic region of its location.

A research for Brazilian case has the following motivations: a) to be largest country in Latin America; b) poor income distribution, that is, social inequality (ONU, 2018); c) ranked $42^{\text {nd }}$ in the ranking of wage inequality in a list of 44 countries, ranking only in front of Costa Rica and South Africa (OECD, 2018). 
According to Fox and Fox (2008) the issue of wage inequality has been ignored by the labor market. The authors consider this as regrettable, because for decades the women have grown in the labor market. In addition, the authors highlight that in the face of (for) structural changes there has been demand for women in the labor market and the supply of jobs to them (for women) will continue to grow in all sectors. In this sense, the research contributes to observe this problem in a specific context.

The research, analyzing all the geographic regions of Brazil, expands the conclusions of the study by Silva, Dal Magro and Silva (2016) who found factors that explain the wage of accountants in specific regions. For Haynes (2017), accounting is a political construct that is already known to perpetuate wage inequality, mainly due to the global challenges related to gender, which throughout history represents a difficult barrier to overcome.

Considering that accounting positions are disseminators and perpetuators of the company information, this study justifies the focus on professionals who represent companies, which are organizations. Therefore, it should at least be an example to society, showing that, in accounting, wage inequality should be as small as possible. Thus, it is possible to see that the accounting area is a promising field for this study.

In addition, there is a need to understand the causes of wage differences between different positions in accounting. In order to develop actions that minimize the discrimination in the accounting area. Therefore, knowing the determinants of the wage difference of the accounting area, it contributes to the reflection and implementation of actions.

Those actions must be taken to reduce wage gaps. Especially those endogenous gaps to discriminatory factors since the solution of this problem contributes to the development of the profession. Thus, it is important to indicate a greater solidity (strength) in this labor market. Furthermore, it stimulates the incoming workers and consolidates some prominence of this profession in the national scenario.

Therefore, an important contribution of this research accrues in the possibility of dimensioning the factors that generate the wage discrimination (core of the problem). Thus, it is feasible to identify the variables that demand the greater attention from those who work in the accounting area, such as professionals or academics.

Knowing the discriminatory forces also help in the identification of the main inequalities that affect the income distribution of a population. The outcomes can subsidize the policymakers to design redistributive measures, as well as the evaluation of their impact on the well-being of a society (CASTELLANO, MANNA and PUNZO, 2016). Undoubtedly, knowing the determinants is important for choosing the better public policies (CAMPANTE, CRESPO and LEITE, 2004). These policies will reduce the wage gap and to improve the income distribution.

The research also contributes to consider the heterogeneity of Brazilian geographic regions. With this empirical strategy, the outcomes are expected to show different wage differentials between the regions of the country. In addition, there is a gender wage gap, which the outcomes of the research make possible to set an agenda that promotes equal wage. As far as the proficiency of the accounting professionals, the research brings relevant things to talk about the formal skills of the accountants. Considering the proficiency for accounting work as essential, consider this variable for public police can result in an accurate training supply in some Brazilian regions.

\section{THEORETICAL FRAMEWORK}

The Human Capital Theory and the Segmentation Theory are presented in the following sections. The past-related studies are approached to variables and to results that contribute to the work proposed in this research.

\section{The Human Capital Theory and Segmentation Theory}

According to Helal (2005), the theorists of Human Capital Theory, (see for example, Becker, 1964 and Mincer, 1974), consider that the larger human capital stock of the individual, the greater its marginal productivity. Consequently, the higher the economic value of this individual to the job market as well as the greater your chance of getting a job. 
As discussed by Pfeffer and Langton (1988), the Human Capital Theory predicts that changes in demographic and productivity characteristics can lead to gaps in wages, regardless of corporate norms or arrangements. In turn, Hanushek (2013) highlight that researches of Schultz (1961), Becker $(1964)$ and, Mincer $(1970,1974)$ contributed to disseminate the theoretical and empirical approach to the Theory of Human Capital. It is because they have shown that the wage gap is caused by skill differences, that is, by human capital.

Subsequently, Neves and Fernandes (2002) did a review of the contents and observed that the variables schooling and working time are frequently used. Being schooling is considered the main factor of human capital. For the authors, the occupational structure (position) and class position (base managerial authority) are relevant to explain the wage framework process.

In addition, class position plays an important role as mediator between schooling and wage. Also, in relation to education, Mincer (1974) argues that education is responsible for skills. As a result, this variable has been used as a proxy to measure human capital and to understand wage inequality.

Igbaria and Chidambaram (1997) investigated gender gap, human capital variables (age, working time, education and organizational level) and factors that explain career success. The findings concerning women are such that: a) typically have lower education; b) have less working time; c) have less professional and managerial skills. The authors attributed these differences to the higher turnover of women and career breaks to prioritize family. They also concluded that the explanation of human capital is linked to the voluntary choices of individuals in allocating investments such as time and effort at work and in the family.

However, the Human Capital Theory has been criticized. Helal (2005) considers this theoretical approach is restrictive and by having a neoclassical economic approach, disregards the social features of employment and the settlement of wages. In addition, Darity (1993) notes that since 1970 the Segmentation Theory is an alternative or complementary theoretical basis to the Human Capital Theory. Because the Segmentation Theory is used to explain labor market behavior.

The Segmentation Theory presupposes that labor market changes, restructuring, and decentralization can provide insight into how labor market identities are produced from the experience gained by holding positions (BAUDER, 2001). According to Bauder (2001), in contrast to human capital theory, segmentation theory advocates that there is no harmonization with a universal market mechanism, between workers and jobs. Jobs are allocated in segments within the labor market, i.e., kind of job (occupation) and position.

Thus, The Segmentation Theory constitutes a theoretical lens useful to explain the economic marginalization of workers, racial minorities, as well as women (BAUDER, 2001). Morrison (1990) explained that to improve The Segmentation Theory is necessary to create a connection between theory and practice. In addition, the labor market should be considered in its geographical context (local, regional, spatial). Dibb and Simkin (2009) report that there are a few researches devoted to analyzing the 'practice' in which segmentation occurs. It can be observed that both The Human Capital Theory and The Segmentation Theory are not free of criticism and have limitations.

However, these issues do not minimize the relevance of these theories as a guide to apply in business and economic sectors. In the case of this research, Human Capital Theory is adopted to explain wages, according to schooling, qualifications, training and professional improvement. The Segmentation Theory, in addition to explaining schooling, considers that wages are most related to the kind of job that workers can have and the position (particularly in this research: Accounting Assistants, Auditors and Accountants).

\section{Determinants of Wage Inequality}

The wage gap attracts the attention from a great part of the public and the private organizations. On the other hand, in the academic context (universities), that are based on epistemology, both phenomenological and positivist, the researcher's intent to understand antecedents, consequences and contexts. They also seek to identify motivating factors of the wage inequality among workers, broadening the scope of research on social inequalities. 
Dunlop (1957) stressed the need for collective bargaining agreements for wage negotiations, whether local or regional, because the absence of these agreements may imply wage differences in the same municipality, state, region or country. This author does not consider the situation as beneficial.

Regarding the ethnicity of the individuals and wage difference by geographic region, Campante, Crespo and Leite (2004) explain that in Brazil there is a phenomenon known as "whitening", that is, the poor individual refers to himself as black or brown, differently from the economically successful person who, although having the same characteristics, identifies himself as Caucasian. This behavior can bias searched outcomes on the wage gap between Caucasians and Blacks, especially in the Northeast and Southeast of Brazil. For the authors, another significant factor in the increase of discrimination is schooling. Ethnicity and schooling tend to influence the entry in the labor market and wages.

Fields and Yoo (2000) quantified the importance of factors that contribute to the reduction of wage inequality in Korea. These factors are tenure or experience, gender, schooling, position wage, company size and region. The most important to explain the inequality of wages are schooling, position and experience. In addition, they found that wage inequality declined among men, but not among women.

Hossain, Haque and Haque (2015) investigated the factors that determine wage differentials in Bangladesh. They found that schooling, age, and gender determined the differences in wages. The authors suggest that this issue should be considered by policymakers to improve income distribution.

In African countries, Agbodji, Batana and Ouedraogo (2015) investigated gender inequality as well as regional inequalities. Regarding gender, women got lower wages than men. In this context, Dreher, Gehring and Klasen (2015) found that gender inequality is one of the key indicators affecting many developing countries. For Jayachandran (2015), men have higher wages than women in almost all countries. Although in recent years, in developing countries, the wage gap is not as large as in the past, even if there is still a difference. However, there is a quasi-consensus that, regardless of the country, there is or should have policy actions to eradicate this inequality.

As reported by Fox (1981), the disparity between men and women in relation to wages, power and prestige occurs almost everywhere in the world. In Fox's (1981) survey, which compared wages for men and women, the author concluded that wages for women are lower. Another conclusion was that men are less susceptible to wage variations due to differences in ethnicity and citizenship.

Konrad and Pfeffer (1990) analyzed the factors that affect the relationship between productivity, publications and wage. Based on a sample of 5,645 university researchers from 200 educational institutions, the authors concluded that productivity explains wages and that human capital theory explains this relationship. In turn, Gerhart and Milkovich (1990) evaluated the determinants and consequences of wage differences between a group of university and high school managers. To do this, they used longitudinal data from 14,000 managers from 200 educational institutions. Although they concluded that there were significant differences in wages, the research was unable to identify the determinants of the wage gap.

In the context of accounting, Fields (2003) investigated wage inequality in the United States from 1979 to 1999. Explanatory variables include gender, ethnicity, experience (time of employment), schooling, position, economic sector and region. The author concluded that explanatory variables of wage inequality are schooling, position, experience (time of employment) and gender.

Bruno (2010), which aimed to analyze the wage differences of Tunisians in the labor market in Paris, did a similar research. Using a linear regression model, the author concluded that, for the whole sample, gender and nationality was not significant. However, when analyzed by economic sector, it identified significant wages differences between women and men, foreigners and native citizens.

According to Haynes (2008), in developed countries, more and more women and men have equality in the positions held, legal rights, access to education and voting power. The women have been active in areas previously dominated by men, that is, they have diversified their positions. However, while there are improvements in terms of formal equality, inequalities and problems remain. Examples are: (i) small number of women in high political and business positions; (ii) imbalance in domestic work (overload for women); (iii) unequal wage and (iv) sexual harassment. 
In turn, Silva, Dal Magro and Silva (2016) aimed to identify the gender inequalities in the accounting, analyzed from the perspective of The Glass Ceiling. They investigated workers in the southern region of Brazil. The results revealed that men more often occupy the positions of auditor and accountant. In addition, men have higher wages, as well as positions held by men are more frequent in large companies. Thus, the authors concluded that there is The Glass Ceiling in the accounting career, which creates an invisible barrier in women's access to higher positions and better wages.

The research of Castellano Manna and Punzo (2016) aimed to identify the factors that explain the wage gap in France and Italy. The data used was from 2004 to 2007, before the economic crisis. The variables examined was gender, age, schooling, experience (time of job), position and wage. The results confirmed that in Italy, redistributive policies worsen the inequality, and in France, this effect is mitigated by job tenure and wages, and social policies. In addition, the authors emphasize that France is traditionally more egalitarian than Italy. In other words, Italy presents a larger wage gap, even with a similar proportion of individuals of each gender.

Recently Haynes (2017) considered that, in general, in 25 years, many things have changed. However, few changes have occurred in relation to gender wage inequality in accounting area. Although there has been advance in the accounting profession, inequalities persist, and it is worrying. An important change is that women can now choose jobs more flexible, especially part-time.

This allows women to compose multiple tasks, especially childcare and other household chores. Consequently, women who choose to temporarily reduce their workload because of family things tend to be disadvantaged. In many cases, for these women, it makes it difficult to improve their career, as well as suffer imputation of depreciatory stereotypes and discrimination. However, above all there is the explicit question of receiving lower wages.

\section{METHODOLOGICAL PROCEDURES}

This research is classified as descriptive, documentary and quantitative. The data was collected in the micro database of the Relação Anual de Informações Sociais (RAIS), available on the website of the Ministério do Trabalho e Emprego (MTE). The selected period was from 2009 to 2015, that is, seven years. The RAIS is a general government database for labor market control. In this database, all companies in the country report annually on a mandatory basis the data about their employees (wages, bonus, workload, time, etc.). Therefore, it allows the generation of longitudinal census statistical data on the employees of the formal labor market.

The sample selected for study (after processing the raw data) is comprised of accounting professionals, with the positions of auditor, accountant, and accounting assistant. Respectively, the employment contract registration, according to the Código Ocupacional Brasileiro (CBO), refers to the positions of: Auditor - СBO 252205, Accountant - СВO 252210 and Accounting Assistant - CBO 413110.

It should be emphasized that the accounting worker population includes only employees hired to work in these positions and does not include partners or any other hiring regime. Thus, the sample size is composed of 60,447 observations for 2009; 72,676 observations for $2010 ; 86,585$ observations for 2011; 88,013 observations for 2012; 91,817 observations for 2013; 91,104 observations for 2014; and 80,881 for 2015.

All annual data was downloaded from MTE database and introduced to the Access software by Microsoft Corporation . The first objective was to filter the data for the three positions to be analyzed and seven years. Subsequently, the filtered data was transferred to Excel software. In this stage, was excluded the data with possible registry mistake made by companies. The information excluded was those inherent to employees who did not complete high school and those classified as inactive.

Finally, the following variables was tabulated: payment (sum of wage, bonus and other remunerations), position, gender, ethnicity, age, schooling, kind of disability, company size (number of workers), kind of movement (hire, dismissal, normal work or leave in the reporting year) and State (grouped by geographic region). 
The values of wages and other remunerations, 2009-2014, was monetarily updated for the year 2015. This was done with the IGP-M (Índice Geral de Preços de Mercado), estimated by FGV (Fundação Getulio Vargas/Brasil). Thus, it was possible to estimate the average wage of the survey years and estimate for each year, the multiple regression model with dummy variables. For the statistical analysis, the variables were categorized according to Box 1.

Box 1

Categorization of variables

\begin{tabular}{|c|c|c|}
\hline Variables & Categorization & References for Include Variables \\
\hline $\begin{array}{l}\text { Monthly Wage (total } \\
\text { earning- sum: wage, } \\
\text { bonus and others) }\end{array}$ & $\begin{array}{l}\text { Monetary value (R\$- } \\
\text { Reais - 2009/2015) }\end{array}$ & $\begin{array}{l}\text { Fox (1981); Konrad and Pfeffer (1990); Gerhart and Milkovich (1990); Fields and } \\
\text { Yoo (2000); Fields (2003); Haynes (2008); Bruno (2010); Agbodji, Batana and } \\
\text { Ouedraogo (2015); Brighenti, Jacomossi and Silva (2015); Dreher, Gehring and } \\
\text { Klasen (2015); Hossain, Haque and Haque. (2015); Jayachandran (2015); Silva, } \\
\text { Dal Magro and Silva (2016); Haynes (2017). }\end{array}$ \\
\hline Position & $\begin{array}{l}\text { Auditor } \\
\text { Accounting Assistant } \\
\text { Accountant }\end{array}$ & $\begin{array}{l}\text { Fields and Yoo (2000); Brighenti, Jacomossi and Silva (2015); Silva, Dal Magro } \\
\text { and Silva (2016). }\end{array}$ \\
\hline Gender & $\begin{array}{c}\text { Male } \\
\text { Female }\end{array}$ & $\begin{array}{l}\text { Fox (1981); Fields and Yoo (2000); Fields(2003); Haynes (2008); Bruno(2010); } \\
\text { Agbodji, Batana and Ouedraogo (2015); Brighenti, Jacomossi and Silva (2015); } \\
\text { Dreher, Gehring and Klasen (2015); Hossain, Haque and Haque (2015); Jayachandran } \\
\text { (2015); Silva, Dal Magro and Silva (2016); Haynes (2017). }\end{array}$ \\
\hline Ethnicity & $\begin{array}{c}\text { Caucasian } \\
\text { Indigenous } \\
\text { Black } \\
\text { Asian } \\
\text { Mulatto } \\
\text { No ethnicity defined }\end{array}$ & Fields (2003); Campante, Crespo and Leite (2004). \\
\hline Age Range & $\begin{array}{l}15 \text { a } 17 \\
18 \text { a } 24 \\
25 \text { a } 29 \\
30 \text { a } 39 \\
40 \text { a } 49 \\
50 \text { a } 64 \\
\text { Above } 64\end{array}$ & Brighenti, Jacomossi and Silva (2015); Silva, Dal Magro and Silva (2016). \\
\hline Schooling & $\begin{array}{l}\text { Complete High School } \\
\text { Incomplete college } \\
\text { Complete college }\end{array}$ & $\begin{array}{l}\text { Gerhart and Milkovich (1990); Fields and Yoo (2000); Fields (2003); Campante, } \\
\text { Crespo and Leite (2004); Brighenti, Jacomossi and Silva (2015); Hossain, Haque } \\
\text { and Haque (2015); Silva, Dal Magro and Silva (2016). }\end{array}$ \\
\hline Disability & $\begin{array}{c}\text { Physical (body) } \\
\text { Deaf } \\
\text { Blind } \\
\text { Mental } \\
\text { Multiple } \\
\text { Rehabilitation } \\
\text { Without disability }\end{array}$ & Ministério do Trabalho e Emprego (2016). \\
\hline
\end{tabular}




\begin{tabular}{|c|c|c|}
\hline Variables & Categorization & References for Include Variables \\
\hline 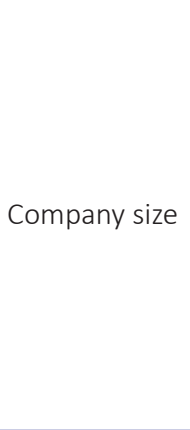 & $\begin{array}{c}\text { From } 0 \text { to } 4 \\
\text { From } 5 \text { to } 9 \\
\text { From } 10 \text { to } 19 \\
\text { From } 20 \text { to } 49 \\
\text { From } 50 \text { to } 99 \\
\text { From } 100 \text { to } 249 \\
\text { From } 250 \text { to } 499 \\
\text { From } 500 \text { to } 998 \\
\text { Above } 999\end{array}$ & $\begin{array}{l}\text { Ministério do Trabalho e Emprego (2016); Fields and Yoo (2000); Brighenti, } \\
\text { Jacomossi and Silva (2015); Silva, Dal Magro and Silva (2016). }\end{array}$ \\
\hline Job & $\begin{array}{c}\text { First job } \\
\text { Reinstated } \\
\text { Temporary } \\
\text { Not first job }\end{array}$ & Fields (2003); Ministério do Trabalho e Emprego (2016). \\
\hline Region & $\begin{array}{l}\text { North } \\
\text { Northeast } \\
\text { Midwest } \\
\text { Southeast } \\
\text { South }\end{array}$ & $\begin{array}{l}\text { Fields and Yoo (2000); Fields (2003); Campante, Crespo and Leite (2004); Agbodji, } \\
\text { Batana and Ouedraogo (2015); Silva, Dal Magro and Silva (2016). }\end{array}$ \\
\hline
\end{tabular}

Source: Search data.

In the statistical analysis, the methodology of multiple regression with binary variables (dummies) was used, that is, variables assuming values of 0 and 1 (GUJARATI and PORTER, 2011). The regressions were performed using STATA statistical software. From this method, it was possible to identify a standard individual that could be compared with the others.

Ex-ante observations and complementary tests showed that: (i) the data are normal (based on sample size); (ii) there are no problems of (perfect) multicollinearity, easily observable by the variables chosen (only dummy variables in the right side of equations to regression analysis); (iii) there is no autocorrelation of the disturbance term because these are regressions on cross-sectional data; (iv) there is no heteroscedasticity, since have not non-binary explanatory variables and; (v) there is no micronumerosity due the sample size.

\section{DATA ANALYSIS AND DISCUSSION}

The data analysis was performed comparatively through the multiple regression model with binary variables, based on the accountant position. The accountant position was omitted in the results of the statistical model because the other positions are compared to this, in a percentage difference (as shown in any result of this kind of estimate, for any software). The result is shown in Table 1. 
Table 1

Statistical model for 2009 data

\begin{tabular}{|c|c|c|c|c|c|c|}
\hline Ln Wage (monthly) & Coef. & Hours. Err. & $\mathrm{t}$ & $P>|t|$ & \multicolumn{2}{|c|}{ [95\% Conf. Interv.] } \\
\hline Auditor & -0.0034784 & 0.0091547 & -0.38 & 0.704 & -0.0214217 & 0.0144649 \\
\hline Accounting Assistant & $-0.5041989(*)$ & 0.0049432 & -102.00 & 0.000 & -0.5138877 & -0.4945102 \\
\hline $\begin{array}{l}\text { Size: } \\
5 \text { a } 9\end{array}$ & 0.0116508 & 0.0066198 & 1.76 & 0.078 & -0.0013240 & 0.0246256 \\
\hline 10 a 19 & $0.0848258\left(^{*}\right)$ & 0.0065152 & 13.02 & 0.000 & 0.0720560 & 0.0975956 \\
\hline 20 a 49 & $0.1681385\left(^{*}\right)$ & 0.0063057 & 26.66 & 0.000 & 0.1557793 & 0.1804977 \\
\hline 50 a 99 & $0.2463770\left(^{*}\right)$ & 0.0069578 & 35.41 & 0.000 & 0.2327397 & 0.2600142 \\
\hline 100 a 249 & $0.2850203\left(^{*}\right)$ & 0.0066012 & 43.18 & 0.000 & 0.2720820 & 0.2979586 \\
\hline 250 a 499 & $0.3366667\left(^{*}\right)$ & 0.0078948 & 42.64 & 0.000 & 0.3211929 & 0.3521404 \\
\hline 500 a 999 & $0.3449819\left(^{*}\right)$ & 0.0093169 & 37.03 & 0.000 & 0.3267207 & 0.3632431 \\
\hline Above 999 & $0.4693768\left(^{*}\right)$ & 0.0097095 & 48.34 & 0.000 & 0.4503461 & 0.4884074 \\
\hline $\begin{array}{l}\text { Schooling: } \\
\text { Complete High School }\end{array}$ & $-0.3437659\left(^{*}\right)$ & 0.0050210 & -68.47 & 0.000 & -0.3536072 & -0.3339247 \\
\hline Incomplete College & $-0.1962161\left(^{*}\right)$ & 0.0052004 & -37.73 & 0.000 & -0.2064088 & -0.1860234 \\
\hline $\begin{array}{l}\text { Age: } \\
15 \text { a } 17\end{array}$ & $-0.3682908\left(^{*}\right)$ & 0.0229653 & -16.04 & 0.000 & -0.4133029 & -0.3232787 \\
\hline 18 a 24 & $-0.2471285\left(^{*}\right)$ & 0.0051779 & -47.73 & 0.000 & -0.2572773 & -0.2369798 \\
\hline 25 a 29 & $-0.1141342\left(^{*}\right)$ & 0.0051368 & -22.22 & 0.000 & -0.1242024 & -0.1040661 \\
\hline 40 a 49 & $0.0700979\left(^{*}\right)$ & 0.0068116 & 10.29 & 0.000 & 0.0567470 & 0.0834487 \\
\hline 50 a 64 & $0.0500103\left(^{*}\right)$ & 0.0107229 & 4.66 & 0.000 & 0.0289934 & 0.0710272 \\
\hline Above 65 & $-0.1651046\left(^{*}\right)$ & 0.0517790 & -3.19 & 0.001 & -0.2665916 & -0.0636177 \\
\hline Prentice & $-0.5942114(*)$ & 0.0490335 & -12.12 & 0.000 & -0.6903172 & -0.4981057 \\
\hline Indigenous & -0.0795907 & 0.0455734 & -1.75 & 0.081 & -0.1689147 & 0.0097332 \\
\hline Black & $-0.0411013(*)$ & 0.0107514 & -3.82 & 0.000 & -0.0621740 & -0.0200285 \\
\hline Asian & $0.0574381\left(^{*}\right)$ & 0.0203516 & 2.82 & 0.005 & 0.0175490 & 0.0973273 \\
\hline Mulatto & $-0.0484528\left(^{*}\right)$ & 0.0048974 & -9.89 & 0.000 & -0.0580518 & -0.0388539 \\
\hline No ethnicity defined & 0.0023379 & 0.0084505 & 0.28 & 0.782 & -0.0142250 & 0.0189009 \\
\hline Female & $-0.0949639\left(^{*}\right)$ & 0.0038325 & -24.78 & 0.000 & -0.1024755 & -0.0874522 \\
\hline $\begin{array}{l}\text { Disability: } \\
\text { Physical (body) }\end{array}$ & $-0.1515977(*)$ & 0.0453535 & -3.34 & 0.001 & -0.2404906 & -0.0627047 \\
\hline Deaf & 0.0085802 & 0.0586156 & 0.15 & 0.884 & -0.1063067 & 0.1234670 \\
\hline Blind & 0.1705001 & 0.9695885 & 0.18 & 0.860 & -1.7298970 & 2.0708970 \\
\hline Mental & -0.1510264 & 0.3202406 & -0.47 & 0.637 & -0.7786990 & 0.4766462 \\
\hline Multiple Disability & -0.3006791 & 0.3201747 & -0.94 & 0.348 & -0.9282225 & 0.3268643 \\
\hline Rehabilitation & 0.2456006 & 0.1848923 & 1.33 & 0.184 & -0.1167890 & 0.6079902 \\
\hline $\begin{array}{l}\text { Type of job: } \\
\text { First job }\end{array}$ & $-0.0946160(*)$ & 0.0065336 & -14.48 & 0.000 & -0.1074220 & -0.0818101 \\
\hline Reinstated & 0.0254369 & 0.0470334 & 0.54 & 0.589 & -0.0667486 & 0.1176224 \\
\hline Temporary & -0.0201764 & 0.0268535 & -0.75 & 0.452 & -0.0728093 & 0.0324566 \\
\hline $\begin{array}{l}\text { Region: } \\
\text { North }\end{array}$ & $-0.1775697(*)$ & 0.0105908 & -16.77 & 0.000 & -0.1983277 & -0.1568117 \\
\hline Northeast & $-0.3013411\left(^{*}\right)$ & 0.0060224 & -50.04 & 0.000 & -0.3131450 & -0.2895373 \\
\hline South & $-0.1274950(*)$ & 0.0050477 & -25.26 & 0.000 & -0.1373886 & -0.1176015 \\
\hline Midwest & $-0.1540139\left(^{*}\right)$ & 0.0069476 & -22.17 & 0.000 & -0.1676312 & -0.1403966 \\
\hline _ constant & $8.05644(*)$ & 0.0065668 & 1226.84 & 0.000 & 8.043569 & 8.069311 \\
\hline \multicolumn{3}{|l|}{$R^{2}$} & \multicolumn{4}{|c|}{0.5229} \\
\hline \multicolumn{3}{|l|}{ No observations } & \multicolumn{4}{|c|}{60.447} \\
\hline
\end{tabular}

Obs: $\left({ }^{*}\right)$ Statistically significant at $5 \%$

Source: Search data.

Cad. EBAPE.BR, v. 18, nº 2, Rio de Janeiro, Abr./Jun. 2020. 
The standard individual, chosen to differentiate the other positions, due the high wage, was: a) holds the position of accountant; b) male; c) Caucasian; d) age between 30 and 39 years old; e) complete university education (graduate); f) has no disability; $\mathrm{g}$ ) at least a second job; h) works in a company with up to four employees; i) from de southeast region. The choice of this individual is justified by the following reasons: 1 ) is the professional with the highest average wage among the positions (in the studied period); 2 ) is the key professional in the area of the accounting, being responsible for all bookkeeping of companies. The comparative analysis is shown in Tables 1, 2, 3 and 4. The Table 2 shows some of the variables and their percentage variations in relation to the standard individual.

Table 2

Percentage variation in relation to the standard individual

\begin{tabular}{l|c|c|c|c|c|c|c|c}
\hline \multicolumn{1}{c|}{ Description } & 2009 & 2010 & 2011 & 2012 & 2013 & 2014 & 2015 \\
\hline $\begin{array}{l}\text { Accountant wage } \\
\text { (monthly) * }\end{array}$ & 3,154 & 3,351 & 3,473 & 3,490 & 3,550 & 3,515 & 3,217 \\
\hline \multicolumn{2}{|c|}{ Percentage variation in relation to the wage of: } \\
\hline Auditor & $*$ & $161.4 \%$ & $108.7 \%$ & $*$ & $91.4 \%$ & $90.0 \%$ & $91.8 \%$ \\
\hline Assistant Accounting & $49.6 \%$ & $49.7 \%$ & $48.8 \%$ & $51.0 \%$ & $51.6 \%$ & $52.6 \%$ & $47.6 \%$ \\
\hline First job & $90.5 \%$ & $93.1 \%$ & $93.5 \%$ & $92.5 \%$ & $92.6 \%$ & $91.8 \%$ & $86.2 \%$ \\
\hline Temporary & $*$ & $92.0 \%$ & $93.4 \%$ & $*$ & $97.4 \%$ & $92.5 \%$ & $*$ \\
\hline Female & $90.5 \%$ & $90.0 \%$ & $90.3 \%$ & $90.8 \%$ & $89.9 \%$ & $89.9 \%$ & $91.4 \%$ \\
\hline Asian & $105.7 \%$ & $105.7 \%$ & $107.0 \%$ & $105.4 \%$ & $*$ & $95.1 \%$ & $*$ \\
\hline Mulatto & $95.2 \%$ & $92.1 \%$ & $94.0 \%$ & $95.4 \%$ & $95.5 \%$ & $94.5 \%$ & $93.2 \%$ \\
\hline Black & $95.9 \%$ & $93.5 \%$ & $92.6 \%$ & $94.0 \%$ & $93.9 \%$ & $92.6 \%$ & $93.4 \%$ \\
\hline No ethnicity defined & $*$ & $98.5 \%$ & $98.4 \%$ & $98.6 \%$ & $*$ & $97.8 \%$ & $98.6 \%$ \\
\hline Complete High School & $65.6 \%$ & $63.5 \%$ & $63.7 \%$ & $65.3 \%$ & $66.3 \%$ & $66.7 \%$ & $66.5 \%$ \\
\hline Incomplete College & $80.4 \%$ & $77.7 \%$ & $77.2 \%$ & $77.1 \%$ & $77.1 \%$ & $77.3 \%$ & $73.5 \%$ \\
\hline $\begin{array}{l}\text { Physical (body) } \\
\text { disability }\end{array}$ & $84.8 \%$ & $*$ & $91.4 \%$ & $83.1 \%$ & $80.1 \%$ & $82.9 \%$ & $78.6 \%$ \\
\hline Deafness & $*$ & $*$ & $*$ & $68.5 \%$ & $78.5 \%$ & $86.1 \%$ & $85.7 \%$ \\
\hline
\end{tabular}

Source: Search data.

* Model did not present statistical significance at the level of $5 \%$, for the variable.

** The standard established by the model: accountant, man, Caucasian ethnicity, age between 30 and 39 years old, complete university education (graduate), with no disability, who is at least acting in his second job, who works in a company with up to four employees and who is from the southeast region.

According to the outcomes, the average wage of the auditor in 2010 was $161.4 \%$ higher than the average wage of the accountant, with significance of $5 \%$. However, in the period studied there was a big drop in the value of the auditor's average wage. In 2013, it can be observed that the average wage of the auditor became (8.6\%) less than the wage of accountant. This should be investigated in future researches, since there is a trend that auditors have higher wages than accountants do.

In the case of the Accounting Assistant, 2014 was the year of higher average relative value of wages since the average wage of the accounting assistant came over the accountant wage (52.6\%). However, in the period studied, this proportion oscillated between $47.6 \%$ and $52.6 \%$ of the accountant wage, that is, a low oscillation (of 5 percentage points), even with positive and negative variations in this proportion. This means that there was no clear trend of real wage gains proportionally to the accountant position.

These results stand out and, it can be inferred that such behavior derives from the economic crisis that has affected Brazil since 2014. As can it be seen, this result was repeated for all positions (accountant, auditor, and assistant accounting) and wages. In addition, the fall in wages in 2015, according to the Instituto Brasileiro de Geografia e Estatística (IBGE, 2018), between 2014 and 2015, had a reduction in real income (inflation adjusted). According to a survey carried out by the Fundação Instituto de Pesquisas Econômicas (FIPE), associated with the Catho Company, from 2014 to 2015, the wages of the new hires, 
Brazilian had an average decrease of $2 \%$. It represents the worst result of the last 11 years (CATHO, 2018). From Table 2, in the accounting area, the wage reduction was more drastic, certainly impacted by the reduction in the number of vacancies occupied, with repercussions on wages.

To the kind of employment shown in Table 1, the standard individual is the professional who is not in his or her first job. In other words, the employee already has some experience in accounting or another area. It can be observed that this worker has higher wage in all the analyzed years. Even compared to the others who are in the first job, or in temporary work. This can be explained by their experience in the labor market (working time), which is in line with the results of Fields and Yoo (2000) and Brighenti, Jacomossi and Silva (2015). Fields and Yoo (2000) consider experience as one of the most important factors in explaining wage differentials.

In addition, proportional wages in general (in relation to the accountant position) decrease from 2010 to 2015, in small reductions during the period. That is, which it has a lower value in 2015 for professionals who were not in their first job, because they obtained a percentage of $86.2 \%$ in relation to the wage of the professional who is not in his/her first job (standard individual); and in relation to temporary work, the lowest variation was registered in 2010 (92.0\%). Thus, it is noticeable that the professional who is not in his first job receives a higher wage than other professionals do. This can be explained by professional experience. However, the wage variation in the kinds of employment is small, since it does not present a relevant difference.

Regarding gender, there was a reduction in the proportional wages of women from 2009 to 2014 and increased in 2015 (91.4\% of the men average wage). That is, in 2015, women had wages a little closer to the standard individual, determinate who is a man. During the period, the difference between men and women was approximately $10 \%$ in favor for men. However, the lower wages scenario for women was repeated over the years, showing that men are still more valued when compared to whom is a man.

The evidence of wage inequality between men and women in Brazil is also found in studies conducted in several Brazilian regions and states, the exemple of Brighenti, Jacomossi and Silva (2015) and Silva, Dal Magro and Silva (2016). This same reality is found in other countries, as reported in Fields and Yoo (2000).

Described by Dreher, Gehring and Klasen (2015), gender inequality is one of the main problems affecting a large part of developing countries. Moreover, for Jayachandran (2015), men have higher wages than women in almost all countries/ regions and in different economic sectors. This may seem normal, but it is not possible to allow, after so much socioeconomic development, that there are no significant changes in relation to this issue. In the accounting profession specifically, Haynes (2017) points out that, even if there have been advances, inequalities persist and worry.

The Pesquisa Nacional por Amostra de Domicílios (PNAD) of IBGE (2018) also showed that there was a reduction in income inequality between men and women, from 74.5\% to 76.1\% between 2014 and 2015 . However, this change may be related to the Brazilian economic crisis, and therefore may be temporary. That result is also confirmed by Silva, Dal Magro and Silva (2016), which found that which is still difficult for women to take higher positions and wages.

When analyzing the ethnic group, Table 1 , it is noted that there is no wage discrimination between blacks and mulattos. The wages ratios of blacks and mulattos, compared to the standard (Caucasian) individual for the period studied, are between $92 \%$ and $96 \%$, approximately. In other words, blacks and mulattos have average wages below Caucasians in the range of about $8 \%$ to $4 \%$, approximately. An emphasis should be placed to Asian ethnicity, who have slightly higher wages than Caucasians, at around $5 \%$ for most of the period analyzed.

Concerning education, individuals with complete high school have lower wages, compared to those with incomplete college and complete college. It should be emphasized that the standard individual who receives a higher wage, it is the individual who has complete college. As the people with complete college, the people with complete high school have lower average wages of about $35 \%$; to those with incomplete college, average wages are lower by around $23 \%$. This result was already expected and is similar to previous studies like Fields and Yoo (2000), Brighenti, Jacomossi and Silva (2015) and Hossain, Haque and Haque (2015).

This result confirms that the Human Capital Theory is emphatic in education and qualification investments, giving the greater wages (Mincer, 1958; Becker, 1964). Concerning the kinds of disabilities, physical (body) and deafness were highlighted. People with different types of disability (body) had a relative average wage, to the standard individual (without any disability), lower by approximately of $17 \%$ (considering the period studied). As for those who were deafness, however, the relative average was still lower, approximately to $20 \%$, considered to the standard individual. 
In most cases, professionals with disability get lower wages. This result is confirmed by ASID (2018) which notes that most of the disabled are not included in the labor market. In addition, $46.4 \%$ of those who declared themselves disabled and occupying different positions receive a minimum wage. Table 3 presents the variation of the age group per year in relation to the standard individual (age between 30 and 39 years).

Table 3

Age Range

\begin{tabular}{|c|c|c|c|c|c|c|c|}
\hline Classification & 2009 & 2010 & 2011 & 2012 & 2013 & 2014 & 2015 \\
\hline $\begin{array}{l}\text { Wage (monthly) } \\
\text { Reference } * *\end{array}$ & 3,154 & 3,352 & 3,473 & 3,490 & 3,551 & 3,516 & 3,218 \\
\hline \multicolumn{8}{|c|}{ Age Range } \\
\hline Apprentice & $40.6 \%$ & $42.4 \%$ & $30.2 \%$ & $48.5 \%$ & $28.0 \%$ & $37.4 \%$ & $34.7 \%$ \\
\hline 15 to 17 years & $63.2 \%$ & $61.8 \%$ & $62.1 \%$ & $60.9 \%$ & $63.7 \%$ & $64.1 \%$ & $81.8 \%$ \\
\hline 18 to 24 years & $75.3 \%$ & $75.0 \%$ & $74.9 \%$ & $74.7 \%$ & $75.2 \%$ & $75.2 \%$ & * \\
\hline 25 to 29 years & $88.6 \%$ & $88.8 \%$ & $87.9 \%$ & $87.6 \%$ & $89.0 \%$ & $88.7 \%$ & $100.9 \%$ \\
\hline 40 to 49 years & $107.0 \%$ & $107.0 \%$ & $106.8 \%$ & $164.0 \%$ & $107.7 \%$ & $106.8 \%$ & $118.8 \%$ \\
\hline 50 to 64 years & $105.0 \%$ & $104.1 \%$ & $102.2 \%$ & $105.6 \%$ & $104.6 \%$ & $105.0 \%$ & $116.8 \%$ \\
\hline $\begin{array}{l}65 \text { years or } \\
\text { more }\end{array}$ & $83.5 \%$ & $82.9 \%$ & $86.6 \%$ & $*$ & $*$ & $79.6 \%$ & $109.4 \%$ \\
\hline
\end{tabular}

Source: Search data.

* Model did not present statistical significance at the level of $5 \%$, for the variable.

** The standard established by the model: Accountant, man, Caucasian ethnicity, between 30 and 39 years of age, complete university education (graduate), with no disability, who is at least works in his second job, who works in a company with up to four employees and who is from southeast region.

It can be observed that, among the age groups, when the age increases, the relative average wage rises gradually against the average wage of the standard individual (30 to 39 years old). People between the ages of 40 and 64 have a relative average wage higher than the average wage of the standard individual (approximately 18\%).

Another result here is that it should be highlighted that for people being over 65 years old, the average wage is lower than the average wage standard individual is, i.e. having a wage of about $12 \%$ lower than the standard individual. In addition, it has a wage $18 \%$ lower than the age range between 50 and 64 years old. In other words, when the person reaches the age 65 years old and he or she needs to continue working, the average wage decreases to approximately $18 \%$. Table 4 presents the wage gap, according to company size, with the standard individual, in this case, the employee of a company with up to four employees. 
Table 4

Company size

\begin{tabular}{l|c|c|c|c|c|c|c}
\hline \multicolumn{1}{c|}{ Classification } & 2009 & 2010 & 2011 & 2012 & 2013 & 2014 & 2015 \\
\hline $\begin{array}{l}\text { Wage Reference } \\
\text { (monthly) } *\end{array}$ & 3,154 & 3,351 & 3,473 & 3,490 & 3,550 & 3,515 & 3,217 \\
\hline \multicolumn{7}{|c|}{ Company size } \\
\hline 5 to 9 employees & $*$ & $102.9 \%$ & $103.2 \%$ & $101.8 \%$ & $101.6 \%$ & $104.5 \%$ & $103.6 \%$ \\
\hline 10 to 19 employees & $108.5 \%$ & $110.3 \%$ & $109.6 \%$ & $108.3 \%$ & $107.3 \%$ & $109.3 \%$ & $109.0 \%$ \\
\hline 20 to 49 employees & $116.8 \%$ & $117.1 \%$ & $116.2 \%$ & $115.6 \%$ & $114.0 \%$ & $114.8 \%$ & $114.0 \%$ \\
\hline 50 to 99 employees & $124.6 \%$ & $122.4 \%$ & $123.2 \%$ & $122.3 \%$ & $119.0 \%$ & $120.6 \%$ & $120.7 \%$ \\
\hline 100 to 249 employees & $128.5 \%$ & $129.4 \%$ & $129.8 \%$ & $127.5 \%$ & $125.4 \%$ & $127.0 \%$ & $126.9 \%$ \\
\hline 250 to 499 employees & $133.7 \%$ & $135.9 \%$ & $133.1 \%$ & $133.3 \%$ & $128.9 \%$ & $129.9 \%$ & $131.3 \%$ \\
\hline 500 to 999 employees & $134.5 \%$ & $135.5 \%$ & $132.1 \%$ & $135.6 \%$ & $135.6 \%$ & $132.2 \%$ & $125.1 \%$ \\
\hline 1,000 or + employees & $146.9 \%$ & $149.5 \%$ & $144.5 \%$ & $141.6 \%$ & $137.0 \%$ & $138.2 \%$ & $132.0 \%$ \\
\hline
\end{tabular}

Source: Search data.

* Model did not present statistical significance at the level of $5 \%$, for the variable.

** The standard established by the model: accountant, man, Caucasian ethnicity, between 30 and 39 years of age, complete university education (graduate), with no disability, who is at least works in his second job, who works in a company with up to four employees and who is from the southeast region.

The standard individual is the person who works in companies with up to four employees, so he is an employee of small businesses. It is noticed that, in general, the more employees in the company, the higher wage of employees in the accounting area. It is common to all years analyzed, since the variation exceeds $100 \%$, that is, the wage of these professionals is higher than the wages of those who work in companies with up to four employees.

It is noteworthy that in 2015 , the variation of all professionals was reduced, however, this reduction was small. The outcomes corroborate with the findings of Fields and Yoo (2000), Brighenti, Jacomossi and Silva (2015) and Silva, Dal Magro and Silva (2016) that identified that the size of the company affects the wages. Finally, with respect to Table 5, on the Brazilian regions, there is the wage difference to professional in the Southeast region (individual standard).

Table 5

\section{Geographic Region}

\begin{tabular}{ll|l|l|l|l|l|c|c}
\hline \multicolumn{1}{r|}{ Classification } & 2009 & 2010 & 2011 & 2012 & 2013 & 2014 & 2015 \\
\hline Wage (monthly) ** & 3,154 & 3,351 & 3,473 & 3,490 & 3,550 & 3,515 & 3,217 \\
\hline \multicolumn{7}{c}{ Region } \\
\hline North & $82.2 \%$ & $89.8 \%$ & $79.5 \%$ & $78.0 \%$ & $78.1 \%$ & $80.3 \%$ & $80.3 \%$ \\
\hline Northeast & $69.9 \%$ & $71.8 \%$ & $69.6 \%$ & $71.5 \%$ & $72.2 \%$ & $72.4 \%$ & $74.9 \%$ \\
\hline South & $87.3 \%$ & $86.1 \%$ & $86.4 \%$ & $88.5 \%$ & $89.0 \%$ & $89.6 \%$ & $91.6 \%$ \\
\hline Midwest & $84.6 \%$ & $81.2 \%$ & $83.3 \%$ & $85.2 \%$ & $84.8 \%$ & $85.7 \%$ & $88.0 \%$ \\
\hline
\end{tabular}

Source: Search data.

* Model did not present statistical significance at the level of $5 \%$, for the variable.

** The standard established by the model: accountant, man, Caucasian ethnicity, between 30 and 39 years of age, complete university education (graduate), with no disability, who is at least works in his second job, who works in a company with up to four employees and who is from the southeast region. 
Accounting employees located in the South are the ones with the smallest wage difference in relation to those who work in the Southeast region (standard individual); except in 2010, in which the lowest difference was observed for the North region (89.8\%). Therefore, there is a wage discrimination between the Brazilian regions, in favor to the South region (biggest commercial and industrial region of the country). The South (second Brazilian region in economic issue) and Midwest regions are those that are closer to wages paid in the Southeast. On the other hand, the worst wages are those in the Northeast region. The Northeast region was also identified as the one that pays less to professionals in the research of Campante, Crespo and Leite (2004).

According to the results of Campante, Crespo and Leite (2004), the wage in the Northeast is linked to the fact that poor individuals classify themselves as black or mulatto, increasing the wage gap in this region. However, the current outcomes research is different to the results obtained by these authors, who analyzed intra-region problem. They claim that the Southeast region exceeds the national average of wage discrimination. Fields and Yoo (2000), Agbodji, Batana and Ouedraogo (2015) and Castellano Manna and Punzo (2016) concluded that in many countries there is a wage gap in states and regions, which corroborates with the results found in this research.

From these results, it can be confirmed what the Theory of Segmentation proposes. That is, employees may receive different wages even if they are equally productive. In this case, the segmentation occurs precisely when individuals with similar characteristics receive different wages (SOUZA, 1978).

\section{CONCLUSIONS}

This research aimed to describe the determinants that affect the wage gap between employees in accounting in Brazil from 2009 to 2015. The accounting professionals analyzed in this study are Accounting Assistants, Accountants and Auditors. Multiple regressions with dummy variables were estimated to identify the factors that affect the wage, i.e.: position, gender, ethnicity, age, schooling, disability, company size, employee movement (kind) and regions.

The research was performed analyzing employees, so the age of the companies does not interfere in the outcomes. It is worth mentioning that Brazil is interesting for this research, since it is the biggest country in Latin America and being among the countries with the highest wage inequality in the world. Additionally, accounting professionals are part of an important sector for companies as well as are a prominent professional group.

From the results, it can be concluded that, regarding the problem and purpose of the research, a standard individual was chosen, which represents the most frequent characteristics of an accounting professional. The characteristics are: man, Accountant, employee of a company with up to four employees, complete university education (graduate), aged between 30 and 39 years old, white, have no type of disability, are (at least) second job and are of the Southeast region of Brazil.

For higher average wages it is necessary to change at least one of these characteristics (standard individual). The accountant must work in a large company, especially with more than a thousand employees. Or, another possibility of obtaining higher wages is when the employee (Accountant) is in the age group between 40 and 49 years old. Therefore, professionals who have the characteristics of the standard individual, adjusted to these latest changes, have the highest wages (based on data). This endorses what is exposed in the Human Capital Theory and Segmentation Theory.

Based on the results, it is possible to evaluate some issues and propose actions to reduce the wage gap between the companies and among professionals. This contributes to the creation of a wage base at different levels of performance. This action is important for the accounting area because it provides greater guarantee and incentive to the profession in the national scenario (JEACLE, 2011). As already stated by Campante, Crespo and Leite (2004) and Hossain, Haque and Haque (2015), some public policies must be considered to reduce social and wage inequality across the country. On inequality between men and women, Jayachandran (2015) points out that in any country, developed or not, politicians have many tools to accelerate the process of reducing inequality. 
The research contributes to some issues that need attention, because they represent discrimination, such as the disabled, whose wage inequality is big. At the same time, women receive lower wages and find it very difficult to occupy higher positions. The region of the country and ethnicity are also factors that make the scenario of inequality relevant and, therefore, some private or public actions are necessary to improve this situation. So, no doubt, know the determining factors is important to review and plan public policies and raise awareness among companies. This to reduce the wage inequality that affects a very large number of people around the world.

The limitations of the study concern to data. It does not present information about the time experience of employees, for example. Therefore, it is suggested to extend this research to analyze the experience of employees and verify if the wage gap can be explained by this factor. Another recommendation would be to analyze the coming years with available data, to observe if there will be reduction of inequality in relation to the factors. Another proposal for future studies is the analysis of the impact of the economic crisis on employment and gender in accounting. This is because there was a significant wage reduction, especially from 2014/2015, and the crisis can be an explanatory factor of this phenomenon. 


\section{REFERENCES}

AGBODJI, A. E.; BATANA, Y. M.; OUEDRAOGO, D. Gender inequality in multidimensional welfare deprivation in West Africa: the case of Burkina Faso and Togo. International Journal of Social Economics, v. 42, n. 11, p. 980-1004, 2015.

AÇÃO SOCIAL PARA IGUALDADE DAS DIFERENÇAS - ASID. Censo do IBGE 2010 Revela Realidade da Pessoa com Deficiência no Brasil. Available at: <http://asidbrasil.org.br/censo-do-ibge-2010-revelarealidade-da-pessoa-com-deficiencia-no-brasil/>. Accessed on: May 24, 2016.

BAUDER, $\mathrm{H}$. Culture in the labor market: segmentation theory and perspectives of place. Progress in human geography, v. 25, n. 1, p. 37-52, 2001.

BECKER, G. S. Human capital a theoretical and empirical analysis, with special reference to education. New York: Columbia University Press, 1964.

BRIGHENTI, J.; JACOMOSSI, F.; SILVA, M. Z. da. Desigualdades de sexo na atuação de Contadores e Auditores no mercado de trabalho catarinense. Enfoque: Reflexão Contábil, v. 34, n. 2, p. 109-122, 2015.

BRUNO, A.-S. Analyser les écarts de salaires à l'aide des modèles de régression. Vertus et limites d'une méthode. Le cas des migrants de Tunisie en région parisienne après 1956. Histoire \& Mesure, v. 25, n. XXV-2, p. 121-156, 2010.

CAMPANTE, F. R.; CRESPO, A. R.V.; LEITE, P. Desigualdade salarial entre raças no mercado de trabalho urbano brasileiro: aspectos regionais. Revista Brasileira de Economia, v. 58, n. 2, p. 185-210, 2004.

CASTELLANO, R.; MANNA, R.; PUNZO, G. Income inequality between overlapping and stratification: a longitudinal analysis of personal earnings in France and Italy. International Review of Applied Economics, v. 30, n. 5, p. 567-590, 2016.

CATHO. Queda no salário de admissão se intensifica em junho e tem segundo pior resultado em 11 anos. 2016. Available at: <http:// www.catho.com.br/institucional/2015/08/queda-no-salario-deadmissao-se-intensifica-em-junho-e-tem-segundo-pior-resultadoem-11-anos/>. Accessed on: May 24, 2018.

DARITY, W. A. Labor economics: problems in analysing labor markets. Springer Science \& Business Media, 1993.

DIBB, S.; SIMKIN, L. Bridging the segmentation theory/practice divide. Journal of Marketing Management, v. 25, n. 3-4, p. 219-225, 2009.

DREHER, A.; GEHRING, K.; KLASEN, S. Gesture politics or real commitment? Gender inequality and the allocation of aid. World Development, v. 70, p. 464-480, 2015.

DUNLOP, J. T. The Theory of Wage Determination. New York: MacMillan \& Co Limited, 1957.

FIELDS, G. S.; YOO, G. Falling labor income inequality in Korea's economic growth: Patterns and underlying causes. Review of Income and Wealth, v. 46, n. 2, p. 139-159, 2000.

FIELDS, G. S. Accounting for income inequality and its change: A new method, with application to the distribution of earnings in the United States. Research in Labor Economics, v. 22, n. 3, p. 1-38, 2003.
FOX, B. J.; FOX, J. Women in the labour market, 1931-81: Exclusion and competition. Canadian Review of Sociology, v. 23, n. 1, p. 1-21, 1986.

FOX, M. F. Sex, salary, and achievement: Reward-dualism in academia. Sociology of Education, v. 54, n. 2, p. 71-84, 1981.

GERHART, B.; MILKOVICH, G. T. Organizational differences in managerial compensation and financial performance. Academy of Management Journal, v. 33, n. 4, p. 663-691, 1990.

GUJARATI, D. N.; PORTER, D. C. Econometria Básica. 5 ed. Porto Alegre: AMGH Editora, 2011.

HANUSHEK, E. A. Economic growth in developing countries: The role of human capital. Economics of Education Review, v. 37, p. 204-212, 2013.

HAYNES, K. Accounting as gendering and gendered: A review of 25 years of critical accounting research on gender. Critical Perspectives on Accounting, v. 43, p. 110-124, 2017.

HAYNES, K. Moving the gender agenda or stirring chicken's entrails? Where next for feminist methodologies in accounting?. Accounting, Auditing \& Accountability Journal, v. 21, n. 4, p. 539-555, 2008.

HELAL, D. H. Flexibilização organizacional e empregabilidade individual: proposição de um modelo explicativo. Cadernos EBAPE.BR, Rio de Janeiro, v. 3, n. 1, p. 1-15, 2005.

HOSSAIN, K. A.; HAQUE, S. M.; HAQUE, A. E. An Analysis of the Determinants of Wage and Salary Differentials in Bangladesh. South Asia Economic Journal, v. 16, n. 2, p. 295-308, 2015.

INSTITUTO BRASILEIRO DE GEOGRAFIA E ESTATÍSTICA - IBGE. PNAD 2015: rendimentos têm queda e desigualdade mantém trajetória de redução. Available at: <http://saladeimprensa.ibge.gov.br/noticias. html?view=noticia>. Accessed on: Apr. 24, 2018.

IGBARIA, M.; CHIDAMBARAM, L. The impact of gender on career success of information systems professionals: A human-capital perspective. Information Technology \& People, v. 10, n. 1, p. 63-86, 1997.

JAYACHANDRAN, $\mathrm{S}$. The roots of gender inequality in developing countries. Economics, v. 7, n. 1, p. 63-88, 2015.

JEACLE, I. A practice of her own: Female career success beyond the accounting firm. Critical Perspectives on Accounting, v. 22, n. 3, p. 288-303, 2011.

KONRAD, A. M.; PFEFFER, J. Do you get what you deserve? Factors affecting the relationship between productivity and pay. Administrative Science Quarterly, v. 35, n. 2, p. 258-285, 1990.

MINCER, J. Investment in human capital and personal income distribution. Journal of Political Economy, v. 66, n. 4, p. 281-302, 1958.

MINCER, J. Schooling, experience, and earnings. New York: NBER, 1974.

MINCER, J. The distribution of labor incomes: A survey with special reference to the human capital approach. Journal of Economic Literature, v. 8, n. 1, p. 1-26, 1970.

MORRISON, P. S. Segmentation theory applied to local, regional and spatial labour markets. Progress in Human Geography, v. 14, n. 4, p. $488-528,1990$. 
MINISTÉRIO DO TRABALHO - MTE. Cadastro Geral de Empregados e Desempregados (CAGED). Available at: <http://trabalho.gov.br/ trabalhador-caged>. Accessed on: May 02, 2018.

NEVES, J. A.; FERNANDES, D. C. Estrutura ocupacional, autoridade gerencial e determinação de salários em organizações fordistas: o caso da indústria de transformações no Brasil. RAC - Revista de Administração Contemporânea, v. 6, n. 1, p. 127-140, Jan./Apr. 2002.

ORGANIZATION FOR ECONOMIC CO-OPERATION AND DEVELOPMENT OECD. Income inequality (indicator). Available at: <https://data.oecd. org/inequality/income-inequality.htm>. Accessed on: June 20, 2018.

ORGANIZAÇÃO DAS NAÇÕES UNIDAS - ONU. América Latina e Caribe é região mais desigual do mundo, revela comissão da ONU. Available at:
$<$ https://nacoesunidas.org/america-latina-e-caribe-e-regiao-mais-desigual-domundo-revela-comissao-da-onu/>. Accessed on: June 20, 2018.

PFEFFER, J.; LANGTON, N. Wage inequality and the organization of work: The case of academic departments. Administrative Science Quarterly, v. 33, n. 4, p. 588-606, 1988.

SCHULTZ, T. W. Investment in human capital. American Economic Review, v. 51, n. 1, p. 1-17, 1961.

SILVA, J. C.; DAL MAGRO, C. B.; SILVA, M. Z. da. Gender inequality in accounting profession from the perspective of the glass ceiling. RACE - Revista de Administração, Contabilidade e Economia, v. 15, n. 2, p. 447-474, 2016.

SOUZA, M. C. C. D. Mercado de trabalho: abordagens duais. Revista de Administração de Empresas, v. 18, n. 1, p. 59-69, 1978.

Mara Vogt

ORCID: https://orcid.org/0000-0002-3951-4637

PhD in Accounting and Business Administration at University Regional of Blumenau (FURB), Blumenau- SC, Brazil. E-mail: maravogtcco@gmail.com

Edmery Tavares Barbosa

ORCID: https://orcid.org/0000-0001-6000-2831

Associate Professor at Federal University of Paraíba (UFPB); PhD student in Accounting at the Faculté de Sciences d'Administration of the Université Laval- Quèbec-Canada; Master in Accounting from University of Blumenau (FURB); Master Recherche en Comptabilité, Management et AuditUniversité Paris Dauphine - Paris, France. E-mail: edmery.tavares-barbosa.1@ulaval.ca

Marcia Zanievicz da Silva

ORCID: http://orcid.org/0000-0003-1229-7705

$\mathrm{PhD}$ in Accounting and Business Administration at University Regional of Blumenau (FURB); Professor at University of Blumenau (FURB), BlumenauSC, Brazil. E-mail: mzsilva@furb.br

Arno Paulo Schmitz

ORCID: http://orcid.org/0000-0001-6924-9611

PhD in Economic Development at Federal University of Parana (UFPR); Associate Professor at Federal University of Parana, Curitiba - PR, Brazil. E-mail: arno@ufpr.br 